\title{
Schimbarea de perspectivă în dramaturgia postbelică sub presiunea comunistă
}

\author{
Drd. ARTAGEA (SOLOMON) Centa \\ Universitatea „Dunărea de Jos” din Galați
}

\begin{abstract}
The spread of the socialist propaganda towards the substance of the post-war drama world solicited the mobilisation of an entire scaffolding in order to avoid its reflexion back, without the protrusion of the desired environment to be submitted. Started from the Bolshevik Russia, looking to preserve the spread speed in our case, the ideological waves had to become members of the same plan through an unitary index of refraction. Thus, the socialist ideology, like in a prism, is separated in more rays, some which risked to unveil the dark face, being stopped in the black body of the selfcensorship. Like through a lens system, the ideological beams considered valid, with the support of the plenary, congresses, magazines etc. were directed, amplified and propagated in order to reach the playwrights, who, at their turn, become "lens" for their readership. At this collectivity, has the beautified image reached, filtered appropriately to the desires of the Communism, trough a suite of mirrors and lens, like in a complex telescope which had to come closer to the two worlds, so different: The Communism and the drama. The analysis of this phenomenon, revealed by the press of that time is the aim of the present study.
\end{abstract}

Key words: refraction, Communism, drama, mystification, post - war

Dramaturgia postbelică intră în zona de interes a Partidului Comunist Român prin două legi succesive: Legea nr. 165 din 18 iulie 1947 și Legea nr. 156 din aprilie 1949, emise pentru restructurarea teatrelor, operelor și filarmonicelor de stat. Republica Populară Română, a cărei existență fusese oficializată în 30 decembrie 1947, învestea dramaturgia cu sarcina de a-i crea o imagine favorabilă. Ei îi revenea responsabilitatea de a ilustra "Grădina Edenului. Visul milenarist. Fără îngeri, fără Dumnezeu. Mult mai sigur: garantat de știință.” [Boia, 2011: 130]. Reprezentanții de seamă ai Partidului Comunist Român inițiau, cu gândul la un demers longeviv, un dialog cu oamenii teatrelor care sau dovedit mai mult refractari decât cooperanți. Din 1944 până în 1989, constant, teatrul românesc a fost un bastion greu de cucerit, cu perioade de infiltrare a ideologiei comuniste și de perioade de rezistență în fața atacurilor. 
Fundamental este faptul că niciodată teatrul românesc, în acest interval, nu a capitulat în fața adversarului politic.

Imaginarul impus dramaturgiei române se subordona modelului stalinist acceptat ca urmare a îndatoririi pe care o avea Republica Populară Română după Eliberarea de la 23 august 1944 față de URSS care ne eliberase de forțele fasciste și imperialiste.

Istoriei dramaturgiei române i se vor adăuga patru decenii care vor determina, prin factorul politic, un parcurs insolit, o alternanță între refracție și reflexie, între permeabilitate și impermeabilitate. Surprinderea sintetică a acestor variații a dramaturgiei române a fost înlesnită de apelul la segmentele temporale ale regimului politic din România stabilite de Ion Simuț în Literaturile române postbelice [Simut,, 2017:158]: 1945-1947, 1948-1953, 1953-1965, 1965-1971, 1971-1989.

Fiind caracterizată mai ales de lupta PCR de a dobândi puterea totală, perioada 1945-1947 aduce falsificarea alegerilor din 1946 și culminează, ca urmare a susținerii sovieticilor, cu arestarea și condamnarea pe viață a conducătorilor PNȚ, Iuliu Maniu și Ion Mihalache, dizolvarea PNȚ și PNL și cu abdicarea regelui Mihai I.

Dramaturgia din 1945-1947, chiar dacă este monitorizată pentru a scrie texte solicitate în spiritul stalinismului, inițiază strategia evitării, a trenării colaborării pentru a determina clemență din partea regimului. Se va apela, până la crearea noilor texte cerute la comanda politică, pentru păstrarea vitalității instituțiilor, la texte create de dramaturgi în interbelic: Steaua fără nume de M. Sebastian, Omul care a văzut moartea de Victor Eftimiu, Visul unei nopți de iarnă de Tudor Mușatescu, Domnișoara Nastasia de G. M. Zamfirescu, Dezertorul de M. Sorbul.

Un început timid de convertire se face simțit în rândul dramaturgilor, puțin cunoscuți până atunci. Apar primele semne ale colaborării prin texte recent scrise de către Tudor Șoimaru (Furtună în Olimp), Vintilă Rusu-Șirianu (Clocot) și, mai ales, prin Omul din Ceatal de M. Davidoglu. În prima etapă, regimul politic se lovește de rezistența dramaturgilor la nou și se întâlnește cu un proces de reflexie, de ricoșare a materialismului dialectic. Oricum, dacă acțiunea comuniștilor asupra teatrului nu dă roade imediat, ele vor fi cuantificate mai târziu, în epocile viitoare: „Măsurile aplicate teatrului atunci (1946) au fost hotărâtoare pentru înflorirea de azi (1984).’[Bărbuță, 1984:7]

Intitulată "supremația stalinismului sau socialismul de tip sovietic" [Simuț, 2017:205], etapa cuprinsă între 1947-1953 este marcată de multe evenimente care schimbă înfățișarea Republicii Populare Române mai ales prin 
înființarea PMR, prin naționalizare și cooperativizare, pedepsirea lui Lucrețiu Pătrășcanu și a grupului Ana Pauker - Vasile Luca - Teohari Georgescu acuzați de „deviaționism de dreapta” [Simuț,2017:167] și adoptarea Constituției de către Marea Adunare Națională după modelul Constiuției lui I. V. Stalin din 1936 și stingerea liderului de la Moscova, urmat de Hrușciov.

Lipsindu-le puterea de a rezista acestor atacuri ale politicului, dramaturgii, înțelegând cât de mult le este îngrădită libertatea, încep să scrie în noua formulă estetică, astfel că sunt imediat publicați și li se montează piesele. Temele specifice dramaturgiei noi apar în Minerii, Cetatea de foc de Mihail Davidoglu, Iarbă rea de Aurel Baranga, Haiducii de Victor Eftimiu, Pentru fericirea poporului de Aurel Baranga și N. Moraru, Ion Vodă cel Cumplit de Laurențiu Fulga, Oamenii de azi de Lucia Demetrius. Pentru a nu lăsa să încolțească în conștiința scriitorilor colaboratori sentimentul remușcării, susținătorii partidului sunt foarte deschiși spre a-i premia în mare măsură. Premiile Academiei R.P.R. pentru dramaturgie sunt acordate pieselor Omul din Ceatal și Minerii de Mihail Davidoglu, Rapsodia țiganilor de Mircea Ștefănescu, Premiul de Stat pentru artă este acordat pieselor Cetatea de foc de Mihail Davidoglu, Pentru fericirea poporului de Aurel Baranga și N. Moraru, Omenii de azi de Lucia Demetrius, Nepoții gornistului de Cezar Petrescu și M. Novicov. Etapa aceasta din evoluția teatrului românesc este probabil fără precedent și fără continuare, dacă evaluăm diacronic socialismul la noi. Viteza de propagare a ideilor socialiste prin teatru crește și, odată cu ea, crește forța de pătrundere a acestora în rândul spectatorilor. Permeabilitatea dramaturgilor permite celor două tărâmuri, politic și artistic, să comunice, dar doar unidirecțional, dinspre solicitantul politic spre executantul dramaturgic. Refracția ideologică se produce și îi determină pe comuniști să se iluzioneze că spectatorii sunt mai aproape de regim. Viața teatrului românesc era influențată de undele ideologice care, deși veneau prin filiera politică și dramatică sovietică, nu se temperau trecând prin spațiul românesc. Refracția este așadar complexă și leagă mai multe medii care sunt, în acest segment al evoluției comunismului la noi, perfect sincronizate și deschise spre absorbție.

„Desovietizarea lentă” și angajarea „spre comunismul național” [Simuț, 2017: 221], specifice pentru anii 1953-1965, aduc variate manifestări dinspre Moscova spre Europa. Multe semne arată o Rusie care se destinde în urma Conferinței de la Geneva, în urma raportului secret al lui Hrușciov care critica „Marea Teroare”, în urma retragerii trupelor sovietice din România. Pe de altă parte, Rusia se manifestă dur față de abateri înregistrate în Europa, sancționând sângeros revoluția anticomunistă din Ungaria. Republica Populară Română 
vrea să-și apere drepturile între partidele comuniste ale blocului sovietic și publică Declarația din aprilie 1964 prin care se afirmă desprinderea de sub tutela URSS și înclinarea spre a colabora cu țările capitaliste.

Față de etapa anterioară, dramaturgia, din cauza „visceralei uri față de superiorul intelectual a individului de joasă extracție venit la putere" [Ștefănescu, 2005:19] este afectată de arestarea unor reprezentanți ai ei precum Vasile Voiculescu, regizoarea Marietta Sadova, criticul de teatru Arșavir Acterian, Ion D. Sîrbu. În plus, această agresiune se producea pe fondul colaborării mai multor oameni de teatru cu socialiștii care publică Mielul turbat de Aurel Baranga, Lumina de la Ulmi de Horia Lovinescu, Schimbul de onoare de Mihail Davidoglu, Afaceriștii de Tudor Șoimaru, Arcul de triumf de Aurel Baranga, Indrăgostiții de Maria Banuș, Patriotica română de Mircea Ștefănescu, Citadela sfărâmată de Horia Lovinescu, Nota zero la purtare de Octavian Sava, Ziariștii de Aurel Mirodan, Trei generații de Lucia Demetrius, Hanul de la răscruce de Horia Lovinescu, Rețeta fericirii de Aurel Baranga, Arborele genealogic de Lucia Demetrius, Judecata focului de Al. Adamescu, Nemaipomenita furtună și Noi cei fără de moarte de Mihail Davidoglu, Ecaterina Teodoroiu de N. Tăutu, In valea cucului de M. Beniuc, Vlaicu și feciorii de Lucia Demetrius, Surorile Boga de Horia Lovinescu, Explozie întârziată de Paul Everac, Uriaşul de la câmpie de M. Davidoglu, Intoarcerea de M. Beniuc, Oameni care tac de Al. Voitin, Pasacaglia de Titus Popovici, Ochiul Albastru de Paul Everac, Marele fluviu își adună apele de Dan Tărchilă, Costache și viața interioară de Paul Everac, Să nu-ți faci prăvălie cu scară de Eugen Barbu, Adam și Eva de Aurel Baranga, Ștafeta nevăzută de Paul Everac, Moartea unui artist de Horia Lovinescu, Himera de Paul Everac, Somnoroasa aventură de Theodor Mazilu, Șeful sectorului suflete de Al. Mirodan, Fii cuminte Cristofor de Aurel Baranga.

Alături de acești dramaturgi colaboratori, vor crea pentru teatrul românesc autori precum Marin Sorescu, Teodor Mazilu și Dumitru Solomon care nu-și vor politiza produsul artistic. Această etapă se remarcă prin interferența unor variate tipuri de interacțiune: colaborarea unor oameni de teatru, încarcerarea unor dramaturgi neaderenți, dar și libertatea altora de a se exprima diferit de canonul consfinţit de partid.

Etapa 1965-1971, numită a „liberalizării perverse” [Simuț, 2017:244] îl are în centru pe Nicolae Ceaușescu ce preia conducerea după moartea lui Gheorghe Gheorghiu-Dej, propunând schimbări pentru reducerea rigorilor ideologice de până atunci. Pe lângă schimbări onomastice, PCR și RSR, Ceaușescu atrage simpatia tuturor când înfruntă Rusia pentru invazia 
Cehoslovaciei. Pentru ca dorința de independență să fie clară, Ceaușescu rostește Declarația cu privire la principiile de bază ale politicii externe a României.

Teatrul este, în continuare, domeniu în care și reprezentanții lui, și intrușii politici își dispută întâietatea. Teatrelor românești li se oferea experiența îndelungată a dramaturgiei rusești care, încă din secolul XIX, mergea pe drumul realismului socialist asigurând spectatorii, creând o relație de mare încredere cu aceștia, că le prezintă, în piese, adevărul exact. Receptivitatea spectatorilor ruși la fenomenul dramaturgic a fost stimulativă pentru teatre care au dezvoltat piese inspirate din frământările din anii de început ai ideologiei socialiste până la epoca de creare și consolidare a tânărului stat sovietic rus. Piesele Orologiul Kremlinului de Nikolai Pogodin, Roadele învățăturii de Tolstoi și Trei surori de Cehov sunt de referință pentru conturarea în conștiința spectatorului a unei imagini pozitive a socialismului ce luptă pentru înlăturarea zgurii burgheze.

Se publică piese care satisfac dorințele partidului precum Omul care și-a pierdut omenia de Horia Lovinescu, Nu sunt turnul Eiffel de Ecaterina Oproiu, Iubesc pe al șaptelea de Coman Șova, Tezaurul lui Justinian de Al. Voitin, Sfântul Mitică Blajinu de Aurel Baranga, Simple coincidențe de Paul Everac, A doua dragoste de Corneliu Leu, Ariciul de la dopul perfect de Ion Băieșu. Și din partea scriitorilor care refuză pactul vin piese valoroase, dar, evident, mai puțin numeroase: Iona și Paracliserul de Marin Sorescu, Tanța și Costel, Iubirea e un lucru foarte mare de Ion Băieșu, Vara imposibilei iubiri, Vis, Cezar, măscăriciul piraților, Acești îngeri triști, Pisica în noaptea Anului Nou de D. R.Popescu și Dumitru Solomon. Dar deschiderea sistemului este și față de dramaturgii aflați în exil precum Eugen Ionescu din piesele căruia se vor monta trei în București (Cântăreața cheală, Regele moare și Scaunele) și unele vor fi editate. Constrângere și libertate pentru dramaturgie simultan, ceea ce risipește energiile creatoare, dar reprezintă și cale de a oferi alternativă demnă celor care nu au găsit ca soluție decât intrarea în dialog cu inamicul artei.

Ultima etapă a acestei perioade, cuprinsă între Tezele din 1971 și cele din1989, numită „socialismul dinastic” [Simuț, 2017:256], arborează decizii politice severe inclusiv pentru teatru căruia îi interzice deschiderea către Occident, îi limitează repertoriul și pregătește definitivarea ,,socialismului de tip sovietic" [Simut,,2017:205] pentru a intra în comunism, refuzând „,perestroika” [Simuț,2017:184] ce era promovată chiar de Moscova.

Teatrului i se oferă o atenție sporită în acest interval când ambițiile lui Ceaușescu erau de a se detașa de Moscova. Cenzura dură este reintrodusă și interzice chiar spectacole pe texte din literatura rusă (Revizorul de Gogol, în regia lui L. Pintilie). Fiind greu de rezistat la acest asalt nou al politicului asupra 
dramaturgiei, ce amintea de teroarea de la începutul instalării socialismului în 1947, din 1971, se pornește un nou exod al oamenilor de cultură și știință, printre care și dramaturgi: Alexandru D. Lungu, George Astaloș, Virgil Tănase, Matei Vișniec. Operele lor, considerate sfidătoare față de norma politică, sunt interzise în reviste de literatură și critică. Fără aceștia care au plecat, dramaturgia română cunoaște opere valoroase prin dramaturgii șaizeciști: D. R. Popescu (Rezervația de pelicani, Paznicul de la depozitul de nisip, Piticul din grădina de vară, Moara de pulbere), M. Sorescu ( Setea muntelui de sare, Matca), N. Breban (Culoarul cu șoareci, Bătrâna doamnă și fluturele) și Fănuș Neagu (Scoica de lemn).

Concluzionând, dramaturgia română postbelică sub presiunea comunistă a trecut, în cele patru decenii, de la reflexia ideologiei spre un proces de refracție constant secondat de tendințe refractare, nesemnând niciodată actul capitulării colective, dar atât de departe de „Utopia Noica” [Simion, 1991:6].

\section{Bibliografie:}

Antofi, Simona, General Dictionary of Romanian Literature - Obverse and Reverse Critical Reception, în Oana Cenac (coord., edit.), International Conference of Common Vocabulary/Specialized Vocabulary: Manifestations of Creativity of Human Language, 6-7 iunie 2014, publicate în volumul MANIFESTARI ALE CREATIVITATII LIMBAJULUI UMAN, 2014, p. 13-19, ISBN:978-606-17-0623-5, Accession Number WOS:000378446400001.

Bărbuță, Margareta, Demnitatea teatrului, Editura Eminescu, București, 1984.

Boia, Lucian, Mitologia științifică a comunismului, Editura Humanitas, București, 2011.

Cenac Oana, Discurs ideologic în "Ateneu" 1965, Actele conferinței internaționale Lexic comun / Lexic specializat. Democratizarea cunoașterii" sau migrația lexicului specializat spre lexicul comun, ediția a X-a, Universitatea „Dunărea de Jos” din Galați, Facultatea de Litere, Centrul de Cercetare Comunicare interculturală și literatură, 19 - 20 mai 2017, publicată în Analele Universității „Dunărea de Jos” din Galați, Fascicula XXIV Lexic comun / lexic specializat, revistă indexată in bazele de date internaționale EBSCO: https://wwww.ebscohost.com/titleLists/cmscoverage.pdf, MLA (Modern Language Association, New York, www.mla.org) MLA International Bibliography \& Directory of Periodicals, CEEOL și Fabula. La recherche en littérature (www.fabula.org), anul X, nr. 2(18) /2017, Editura Casa Cărții de Ştiință, Cluj-Napoca, 2017, ISSN 1844-9476, p. 31-48. 
Cenac Oana, General aspects of current political terminology, în Lexic politic - discurs politic, 2014, p.124-130, ISBN:978-606-17-0633-4, WOS: 000378358200007.

Ifrim, Nicoleta, History and Identity in Post-Totalitarian Memoir Writing in Romanian, CLCWeb: Comparative Literature and Culture (ISSN 1481-4374) http://docs.lib.purdue.edu/clcweb/, nr. 16.1 / March 2014, Purdue University Press, revistă indexată ISI Art and Humanities Citation Index http://docs.lib.purdue.edu/clcweb/vol16/iss1/11/, Accession Number WOS:000333326200011.

Simion, Eugen, Cunoașterea omului la limită, în Caiete Critice, ian. 1 (38)/1991. Simuț, Ion, Literaturile române postbelice, Editura Școala Ardeleană, Cluj-Napoca, 2017.

Ștefănescu, Alex, Istoria literaturii române contemporane, Editura Mașina de scris, București, 2005. 